\title{
Caenibacterium thermophilum gen. nov., sp. nov., isolated from a thermophilic aerobic digester of municipal sludge
}

\author{
Célia M. Manaia, ${ }^{1}$ Olga C. Nunes ${ }^{2}$ and Balbina Nogales ${ }^{3}$ \\ ${ }^{1}$ Escola Superior de Biotecnologia, Universidade Católica Portuguesa, 4200-072 Porto, \\ Portugal \\ ${ }^{2}$ LEPAE-Departamento de Engenharia Química, Faculdade de Engenharia, Universidade do \\ Porto, 4200-465 Porto, Portugal \\ ${ }^{3}$ Area de Microbiologia, Universitat de les Illes Balears, 07071 Palma de Mallorca, Spain
}

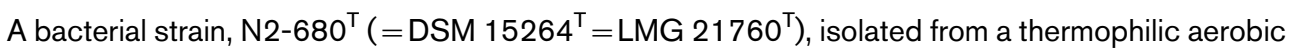
digester of municipal sludge, was characterized with respect to its morphology, physiology and taxonomy. Phenotypically, the isolate was a Gram-negative rod with a polar flagellum, catalase- and oxidase-positive, containing cytoplasmic inclusions of poly- $\beta$-hydroxybutyrate and had an optimal growth temperature of about $47^{\circ} \mathrm{C}$. Strain $\mathrm{N} 2-680^{\top}$ was unable to reduce nitrate and could use organic acids, amino acids and carbohydrates as single carbon sources.

Chemotaxonomic analysis revealed that ubiquinone 8 was the major respiratory quinone of this organism and that phosphatidylethanolamine and phosphatidylglycerol were the major polar lipids. At $50{ }^{\circ} \mathrm{C}$, the major components in fatty acid methyl ester analysis were $\mathrm{C}_{16: 0}$ and cyclo- $\mathrm{C}_{17: 0}$. The highest $16 \mathrm{~S}$ rDNA sequence identity of isolate $\mathrm{N} 2-680^{\top}$ was to Leptothrix mobilis and Ideonella dechloratans (95.7\%) and to Rubrivivax gelatinosus and Aquabacterium commune (95.6\%). 16S rDNA sequence similarities to species of two related thermophilic genera,

Caldimonas manganoxidans and Tepidimonas ignava, were lower (93.6 and $94 \cdot 7 \%$ ). On the basis of phylogenetic analyses and physiological and chemotaxonomic characteristics, it is proposed that isolate $\mathrm{N} 2-680^{\top}$ represents a new genus and species, for which the name Caenibacterium thermophilum gen. nov., sp. nov. is proposed.
\end{abstract}

\section{INTRODUCTION}

The phylogenetic lineage of the $\beta$-subclass of Proteobacteria that includes the genera Rubrivivax, Roseateles, Leptothrix, Ideonella, Aquabacterium and Caldimonas constitutes a heterogeneous group from physiological and ecological perspectives. Bacteriochlorophyll-containing members of this group are represented by the species Rubrivivax gelatinosus (Willems et al., 1991) and Roseateles depolymerans (Suyama et al., 1999). Rubrivivax gelatinosus comprises phototrophic non-sulphur bacteria that occur frequently in sewagetreatment plants and lagoons (Siefert et al., 1978; Pfennig, 1978; Willems et al., 1991). Roseateles depolymerans, isolated from river water in Japan, is an obligately aerobic, heterotrophic organism that produces bacteriochlorophyll $a$ and carotenoid pigments only in the presence of low levels of

Published online ahead of print on 7 February 2003 as DOI 10.1099/ ijs.0.02622-0.

Abbreviation: $\mathrm{PHB}$, poly- $\beta$-hydroxybutyrate.

The GenBank/EMBL/DDBJ accession number for the 16S rDNA sequence of isolate $\mathrm{N} 2-680^{\top}$ is AJ512945. carbon sources. This organism has the ability to degrade biodegradable plastics (Suyama et al., 1998, 1999).

The genus Leptothrix includes sheath-forming bacteria capable of manganese oxidation, occurring in natural iron- and manganese-containing systems (Mulder, 1989; Siering \& Ghiorse, 1996). Members of the genus Leptothrix have been found in both unpolluted natural waters and man-made habitats such as activated sludge (Mulder, 1989; Mulder \& Deinema, 1992). Ideonella dechloratans was isolated from activated sludge and is characterized by its ability to use chlorate as an electron acceptor (Malmqvist et al., 1994). The genus Aquabacterium was defined to accommodate three bacterial strains isolated from biofilm occurring in the Berlin drinking-water distribution system (Kalmbach et al., 1999). These organisms are strict heterotrophs capable of growth on nutrient-rich medium but unable to metabolize carbohydrates.

Among the phylogenetic lineage Rubrivivax-RoseatelesLeptothrix-Ideonella-Aquabacterium, thermophily is represented by the genus Caldimonas (Takeda et al., 2002). 
Caldimonas manganoxidans, the single species within this genus with a validly published name, comprises chemoorganotrophic organisms capable of manganese oxidation and able to grow on poly(3-hydroxybutyrate) (Takeda et al., 1998, 2002). The type strain of Caldimonas manganoxidans has an optimal temperature for growth around $50{ }^{\circ} \mathrm{C}$ and was isolated from a hot spring in Japan, exposed to sun and extensively colonized with cyanobacteria, potential producers of large amounts of poly(3-hydroxybutyrate) (Takeda et al., 1998). More phylogenetically distantly related to this lineage is the thermophile Tepidimonas ignava (Moreira et al., 2000), with an optimal temperature for growth around $55^{\circ} \mathrm{C}$. Tepidimonas ignava, isolated from a Portuguese hot spring, represents a chemolithoheterotrophic organism, capable of using sulphur compounds as an energy source.

This paper reports the isolation and characterization of a thermophilic bacterium enriched on a poly- $\varepsilon$-caprolactone thermoplastic from a thermophilic aerobic digester of activated sludge. Based on phenotypic, chemotaxonomic and $16 \mathrm{~S}$ rDNA-based phylogenetic analysis, the definition of a new genus and species is proposed within the $\beta$-subclass of Proteobacteria with the name Caenibacterium thermophilum gen. nov., sp. nov., and the type strain is $\mathrm{N} 2-680^{\mathrm{T}}$.

\section{METHODS}

Isolation and cultivation conditions. Strain N2-680 ${ }^{\mathrm{T}}$ was isolated from a caprolactone polymer enrichment culture obtained from a thermophilic aerobic digester of a domestic wastewater-treatment plant in northern Portugal. In this treatment process, the decanted sludge is submitted to a mesobiotic anaerobic digestion followed by a thermophilic aerobic digestion, which reaches a maximal temperature of about $60{ }^{\circ} \mathrm{C}$. The product obtained through this digestion was used as inoculum for enrichment. The enrichment was carried out at $50^{\circ} \mathrm{C}$, using $1 \mathrm{~g}$ inoculum per $10 \mathrm{ml}$ mineral medium (medium A; Manaia \& Moore, 2002), supplemented with a pellet of poly- $\varepsilon$-caprolactone thermoplastic (oxepanone homopolymer, with a molecular mass of 80000 ; Solvay). Cultures were transferred weekly to fresh medium for 2 months. Isolate $\mathrm{N} 2-680^{\mathrm{T}}$ was purified from the mixed culture obtained in this enrichment by subculturing on LB broth containing $20 \mathrm{~g}_{\text {agar }} \mathrm{l}^{-1}$ (Carlton \& Brown, 1981). This isolate was maintained on LB agar or cryo-preserved in LB broth containing $15 \%(\mathrm{v} / \mathrm{v})$ glycerol.

Determination of morphological, growth and biochemical characteristics. Colony and cell morphology of strain N2-680 ${ }^{\mathrm{T}}$ were examined using standard protocols (Doetsch, 1981). Cell morphology, Gram-staining reaction, production of spores and the accumulation of poly- $\beta$-hydroxybutyrate (PHB) granules were determined by microscopic examination, following procedures described previously (Doetsch, 1981; Smibert \& Krieg, 1981). The number and position of flagella were determined by light microscopy, after staining the cells with Ryu stain (Heimbrook et al., 1989).

The growth temperature range was examined by measuring turbidity (at $610 \mathrm{~nm}$ ) of cultures in $250 \mathrm{ml} \mathrm{screw}$-capped Erlenmeyer flasks containing $50 \mathrm{ml} \mathrm{LB}$ medium incubated in an orbital water-bath shaker.

Phenotypic tests on isolate $\mathrm{N} 2-680^{\mathrm{T}}$ were carried out as described by Smibert \& Krieg (1981), using 2-day cultures on LB agar. Unless otherwise stated, all incubations were performed at $50^{\circ} \mathrm{C}$. The $\mathrm{pH}$ range for growth was examined in LB medium, using $10 \mathrm{mM}$ MES (Sigma) to adjust the $\mathrm{pH}$ between $5 \cdot 0$ and $6 \cdot 0$ or $10 \mathrm{mM}$ CAPS (Sigma) to adjust the $\mathrm{pH}$ between $9 \cdot 0$ and $11 \cdot 0$. The enzymic activity was tested using the API ZYM system, following the instructions of the manufacturer (bioMérieux). Hydrogenase activity was determined based on the description of Aragno \& Schlegel (1992) and Stöhr et al. (2001). A cell suspension was prepared in sterile phosphate buffer (54 mM, pH 7.2) with cells grown on LB agar and washed twice in the same buffer. This suspension was divided into two sets of aliquots, in rubber-sealed vials. In one set, an atmosphere containing about $80 \%$ $\mathrm{H}_{2}$ was generated, while, in the second set, the atmosphere contained only nitrogen. A solution of triphenyltetrazolium was added in order to obtain a final concentration of $0.25 \%(\mathrm{w} / \mathrm{v})$ and incubated at $50{ }^{\circ} \mathrm{C}$, protected from light. Non-inoculated phosphate buffer as well as phosphate buffer inoculated with an organism lacking hydrogenase activity were used as negative controls. The development of a red colour indicated the reduction of triphenyltetrazolium and the presence of hydrogenase activity.

Manganese oxidation was tested on Sphaerotilus-Leptothrix medium $\left(1^{-1}: 1 \mathrm{~g}\right.$ yeast extract, $1.5 \mathrm{~g}$ peptone, $0.2 \mathrm{~g} \mathrm{MgSO}_{4} .7 \mathrm{H}_{2} \mathrm{O}, 0 \cdot 5 \mathrm{~g}$ ferric ammonium citrate, $50 \mathrm{mg} \mathrm{CaCl}_{2}, 50 \mathrm{mg} \mathrm{MnSO}_{4} \cdot \mathrm{H}_{2} \mathrm{O}, 10 \mathrm{mg}$ $\mathrm{FeCl}_{3} \cdot 6 \mathrm{H}_{2} \mathrm{O}, 20 \mathrm{~g}$ agar, pH $7 \cdot 1$ ). Leptothrix mobilis DSM $10617^{\mathrm{T}}$ was used as a positive control and the presence of manganese oxides was evaluated using benzidinium hydrochloride (Nealson, 1992; Spring et al., 1996). Degradation of the polycaprolactone oxydiethylene ester (CAPA 200; Solvay), a polymer derived from $\varepsilon$-caprolactone with a mean molecular mass of 550, was tested using that polymer $\left(2 \cdot 5 \mathrm{~g} \mathrm{l}^{-1}\right)$ dispersed in agar medium with the following composition $\left(1^{-1}\right): 1 \mathrm{~g}$ $\mathrm{NH}_{4} \mathrm{NO}_{3}, 0 \cdot 2$ g yeast extract, $0 \cdot 25 \mathrm{~g} \mathrm{~K}_{2} \mathrm{HPO}_{4}, 0 \cdot 13 \mathrm{~g} \mathrm{MgSO}_{4}, 0 \cdot 13 \mathrm{~g}$ $\mathrm{NaCl}, 2.5 \mathrm{mg} \mathrm{Fe}\left(\mathrm{SO}_{4}\right)_{3}, 2.5 \mathrm{mg} \mathrm{MnSO}_{4}, 50 \mu \mathrm{g} \mathrm{K} \mathrm{MoO}_{4}, 50 \mu \mathrm{g}$ $\mathrm{Na}_{3} \mathrm{BO}_{3}, 50 \mu \mathrm{g} \mathrm{Co}\left(\mathrm{NO}_{3}\right)_{2}, 50 \mu \mathrm{g} \mathrm{FeCl}_{3}, 50 \mu \mathrm{g} \mathrm{CdSO}_{4}, 50 \mu \mathrm{g} \mathrm{CuSO}_{4}$ and $50 \mu \mathrm{gnSO}_{4}$. Degradation was indicated by the appearance of a clear zone around the colonies.

The nutritional pattern was characterized using the API $50 \mathrm{CH}$ system and a defined medium (medium B) $\left[1^{-1}: 5 \mathrm{~g}\left(\mathrm{NH}_{4}\right)_{2} \mathrm{SO}_{4}, 0.31 \mathrm{~g}\right.$ $\mathrm{KH}_{2} \mathrm{PO}_{4}, 0 \cdot 45 \mathrm{~g} \mathrm{~K}_{2} \mathrm{HPO}_{4}, 1 \cdot 2 \mathrm{~g} \mathrm{Na}_{2} \mathrm{HPO}_{4} \cdot 2 \mathrm{H}_{2} \mathrm{O}, 0 \cdot 1 \mathrm{~g} \mathrm{NaCl}, 0 \cdot 05 \mathrm{~g}$ $\mathrm{CaCl}_{2}, 0 \cdot 4 \mathrm{~g} \mathrm{MgSO}_{4} .7 \mathrm{H}_{2} \mathrm{O}, 5 \mathrm{mg}$ histidine, $20 \mathrm{mg}$ tryptophan, $20 \mathrm{mg}$ methionine, $200 \mu \mathrm{g} p$-aminobenzoic acid, $20 \mu \mathrm{g}$ biotin, $2 \mu \mathrm{g}$ folic acid, $10 \mathrm{mg}$ myo-inositol, $400 \mu \mathrm{g}$ nicotinic acid, $2 \mathrm{mg}$ calcium pantothenate, $400 \mu \mathrm{g}$ pyridoxine hydrochloride, $200 \mu \mathrm{g}$ riboflavin, $400 \mu \mathrm{g}$ thiamin hydrochloride, $500 \mu \mathrm{g} \mathrm{H}_{3} \mathrm{BO}_{3}, 200 \mu \mathrm{g} \mathrm{FeCl}_{3} .6 \mathrm{H}_{2} \mathrm{O}, 400 \mu \mathrm{g} \mathrm{ZnSO}{ }_{4} .7 \mathrm{H}_{2} \mathrm{O}$, $400 \mu \mathrm{g} \mathrm{MnSO}_{4} .4 \mathrm{H}_{2} \mathrm{O}, 40 \mu \mathrm{g} \mathrm{CuSO}_{4} .5 \mathrm{H}_{2} \mathrm{O}, 200 \mu \mathrm{g} \mathrm{Na} \mathrm{MoO}_{4} .2 \mathrm{H}_{2} \mathrm{O}$, $100 \mu \mathrm{g} \mathrm{KI}, 2 \cdot 5 \mathrm{~g}$ agar]. Chemolithoautotrophic growth was tested using medium A supplemented with filter-sterilized $30 \mathrm{mM} \mathrm{NaHCO}_{3}$ and different electron donors. The use of $\mathrm{H}_{2}$ as energy source was tested according to Suyama et al. (1999). The ability to use sulphur or thiosulphate as electron donors was tested by adding $5 \mathrm{~g}$ sulphur flowers $1^{-1}$ to medium A or supplementing the same medium with filter-sterilized sodium thiosulphate at final concentrations of 2.5 and $5 \mathrm{~g} \mathrm{l}^{-1}$. Positive controls, containing $25 \mathrm{mM}$ acetate or acetate and the inorganic electron donor, were run in parallel. The ability to grow in the absence of a source of combined nitrogen was tested using medium A without ammonium sulphate.

The production of photosynthetic pigments was analysed as described by Suyama et al. (1999). Absorption spectra of ultrasonically disrupted cells, pre-grown in medium A supplemented with acetate, were obtained in phosphate buffer.

Determination of genotypic characteristics. For the determination of DNA base composition, genomic DNA was isolated as described by Cashion et al. (1977) and the G+C content of DNA was analysed by HPLC (Mesbah et al., 1989).

$16 S$ rDNA sequence analysis. The nucleic acid sequence of the $16 \mathrm{~S}$ rRNA gene was determined after PCR amplification from total 
DNA extracts, using procedures described previously (Nogales et al., 2001). The primers described by Lane (1991) were used. The nucleotide sequence was compared with reference $16 \mathrm{~S}$ rDNA sequences in the EMBL database using the FASTA program (Pearson \& Lipman, 1988) and subsequently aligned with reference sequences included in the ARB package (http://www.arb-home.de). Evolutionary distances, derived from sequence-pair dissimilarities (Jukes \& Cantor, 1969), were calculated using the PHYLIP package (Felsenstein, 1989). Nonhomologous and ambiguous nucleotide positions were excluded from the calculations.

Determination of chemotaxonomic characteristics. Cultures for polar lipid analysis were grown in LB medium until the end of exponential phase of growth. Lipid extractions were performed as described previously (Prado et al., 1988). Individual polar lipids were separated by one-dimensional TLC on silica gel G plates $(0 \cdot 25 \mathrm{~mm}$ thickness; Merck), using a solvent system of chloroform/ methanol/acetic acid/water ( $80: 17: 10: 4$, by vol.).

For the analysis of methylated fatty acids, isolate $\mathrm{N} 2-680^{\mathrm{T}}$ was cultivated for 3 days on $\mathrm{LB}$ agar at 30 and $50{ }^{\circ} \mathrm{C}$. The harvesting of cells and the preparation of fatty acid methyl esters (FAMEs) were performed as described by Kuykendall et al. (1988). FAMEs were separated as described by Moreira et al. (2000) and the individual components were identified and quantified by comparison with the retention times of authentic standards, using the MIS Library Generation software (Microbial ID Inc.). FAMEs were extracted and analysed at least twice.

For the analysis of respiratory quinones, cells were cultured on LB agar, harvested, freeze-dried and extracted according to Tindall (1989) and the extracts were analysed as described by Moreira et al. (2000).

\section{RESULTS AND DISCUSSION}

Cultivation at $50^{\circ} \mathrm{C}$ in mineral medium supplemented with a poly- $\varepsilon$-caprolactone thermoplastic was used to enrich a thermophilic population capable of using synthetic polymers as the sole source of carbon and energy. The enrichment procedure resulted in a mixed culture containing isolate $\mathrm{N} 2-680^{\mathrm{T}}$, which was purified by successive subculturing on LB agar.

Individual cells of isolate $\mathrm{N} 2-680^{\mathrm{T}}$ were Gram-negative rods, $1.3 \mu \mathrm{m}$ long and $0.5 \mu \mathrm{m}$ wide, containing intracellular PHB granules. A polar flagellum was observed only during the early stages of growth. Endospores, prosthecae or cell sheaths were not observed on isolate $\mathrm{N} 2-680^{\mathrm{T}}$. When cultured on LB agar, strain $\mathrm{N} 2-680^{\mathrm{T}}$ produced non-pigmented colonies, $1-2 \mathrm{~mm}$ in diameter after $36-48 \mathrm{~h}$ growth.

In pure culture, isolate $\mathrm{N} 2-680^{\mathrm{T}}$ was unable to grow in mineral medium A supplemented with the caprolactone polymer used for enrichment. The same medium supplemented with acetate supported growth, even after successive transfers, indicating that this organism does not require specific growth factors, such as vitamins or amino acids. Isolate $\mathrm{N} 2-680^{\mathrm{T}}$ could also grow on nutrient-rich media such as LB. In LB medium, the optimal growth temperature of strain $\mathrm{N} 2-680^{\mathrm{T}}$ was around $47^{\circ} \mathrm{C}$, with a maximal temperature for growth of $57^{\circ} \mathrm{C}$.

The physiological properties of strain $\mathrm{N} 2-680^{\mathrm{T}}$ are summarized in Table 1. Strain $\mathrm{N} 2-680^{\mathrm{T}}$ is composed of oxidase- and catalase-positive, strictly aerobic bacteria, unable to reduce nitrate or nitrite. No photosynthetic pigments or manganese oxidation were observed. This isolate could reduce triphenyltetrazolium in the presence of hydrogen but not in its absence, suggesting that hydrogenase activity is present. However, isolate $\mathrm{N} 2-680^{\mathrm{T}}$ could not grow autotrophically in the presence of hydrogen gas. Autotrophic growth did not occur in the presence of molecular sulphur or thiosulphate as electron donors.

The nutritional pattern exhibited by strain $\mathrm{N} 2-680^{\mathrm{T}}$ was very restricted, since only 11 of the 65 carbon sources tested could support growth. Nevertheless, the carbon sources used represent different chemical classes, namely organic acids, amino acids and hydrocarbons (Table 1). Isolate N2$680^{\mathrm{T}}$ was able to degrade polycaprolactone oxydiethylene ester; growth and polymer degradation were observed after 3 days at $50{ }^{\circ} \mathrm{C}$.

Isolate $\mathrm{N} 2-680^{\mathrm{T}}$ presented poor, but visible growth on mineral medium A with acetate, without ammonium sulphate. However, after two successive transfers under the same conditions, no growth occurred, probably indicating that the cell proliferation observed in the initial cultures was due to the use of nitrogen-containing compounds present in reserve materials. Based on these results, is possible to conclude that isolate $\mathrm{N} 2-680^{\mathrm{T}}$ is unable to use $\mathrm{N}_{2}$ as a nitrogen source.

Analysis of the polar lipid pattern of strain N2-680 ${ }^{\mathrm{T}}$ by TLC revealed the presence of phosphatidylethanolamine (PE) and phosphatidylglycerol (PG) as the major phospholipids. The only respiratory quinone detected was ubiquinone 8 . The predominance of the phospholipids PE and PG and the presence of ubiquinone 8 confirm the inclusion of isolate $\mathrm{N} 2-680^{\mathrm{T}}$ within the $\beta$-subclass of the Proteobacteria (Wilkinson, 1988; Suzuki et al., 1993).

The fatty acid composition of strain $\mathrm{N} 2-680^{\mathrm{T}}$ was analysed using $\mathrm{LB}$ agar cultures grown at 30 and $50{ }^{\circ} \mathrm{C}$ (Table 2). At $30^{\circ} \mathrm{C}$, the predominant components were $\mathrm{C}_{16: 0}, \mathrm{C}_{16: 1}$ and $\mathrm{C}_{18: 1}$, in approximately equal proportions. At this temperature, cyclo- $\mathrm{C}_{17: 0}$ represented only $6 \cdot 5 \%$ of the total fatty acids. At $50{ }^{\circ} \mathrm{C}, \mathrm{C}_{16: 0}$ and cyclo- $\mathrm{C}_{17: 0}$ represented about $70 \%$ of the total FAMEs. Since cyclopropane fatty acids are secondary products of fatty acid biosynthesis (Suzuki et al., 1993), the use of cyclo-fatty acids as chemotaxonomic markers should be considered with caution. However, appreciable amounts (more than $20 \%$ ) of the fatty acid cyclo- $\mathrm{C}_{17: 0}$ were reproducibly detected when this isolate was cultivated for 1 and 3 days at $50^{\circ} \mathrm{C}$. The hydroxy fatty acids $3-\mathrm{OH}-\mathrm{C}_{10: 0}$ and $3-\mathrm{OH}-\mathrm{C}_{12: 0}$ were detected at 30 and $50{ }^{\circ} \mathrm{C}$. Temperature-induced variations in the fatty acid composition of isolate $\mathrm{N} 2-680^{\mathrm{T}}$ agree with the tendency observed for other moderately thermophilic Proteobacteria, in which higher growth temperatures induce an increase in the content of cyclic fatty acids and a decrease in the degree 
Table 1. Phenotypic characteristics of isolate $\mathrm{N} 2-680^{\top}$

+ , Positive result or growth; -, negative result or no growth. Strain N2-680 ${ }^{\mathrm{T}}$ was unable to use these compounds as sole sources of carbon: aesculin, erythritol, D-arabinose, ribose, D-xylose, L-xylose, adonitol, methyl $\beta$-xyloside, galactose, D-glucose, D-fructose, D-mannose, L-sorbose, rhamnose, dulcitol, inositol, mannitol, sorbitol, methyl $\alpha$-D-mannoside, methyl $\alpha$-D-glucoside, $N$-acetylglucosamine, amygdalin, arbutin, salicin, maltose, lactose, melibiose, sucrose, trehalose, inulin, melezitose, D-raffinose, starch, glycogen, xylitol, $\beta$-gentiobiose, Dturanose, D-lyxose, D-tagatose, D-fucose, L-fucose, D-arabitol, L-arabitol, 2 ketogluconate, 5-ketogluconate, malate, hydroxyproline, L-glycine, L-histidine, DL-methionine, L-arginine and L-asparagine. The following enzymes were absent from isolate $\mathrm{N} 2-680^{\mathrm{T}}$ : trypsin, $\alpha$-chymotrypsin, $\alpha$-galactosidase, $\beta$-galactosidase, $\beta$-glucuronidase, $\alpha$-glucosidase, $\beta$-glucosidase, $N$-acetyl- $\beta$-glucosaminidase, $\alpha$-fucosidase and $\alpha$-mannosidase.

\begin{tabular}{|c|c|c|c|}
\hline Characteristic & Response & Characteristic & Response \\
\hline Presence of: & & Growth in presence of/at: & \\
\hline Polar flagellum & + & Penicillin G (10 U) & + \\
\hline Catalase & + & Ampicillin $(10 \mu \mathrm{g})$ & + \\
\hline Cytochrome- $c$ oxidase & + & Nalidixic acid $(30 \mu \mathrm{g})$ & - \\
\hline PHB & + & $3 \% \mathrm{NaCl}$ & + \\
\hline Photosynthetic pigments & - & $4 \% \mathrm{NaCl}$ & - \\
\hline Utilization of carbon sources: & & $\mathrm{pH} 5$ & - \\
\hline Acetate & + & $\mathrm{pH} 6$ & + \\
\hline Citrate & + & $\mathrm{pH} 9$ & + \\
\hline Gluconate & + & $\mathrm{pH} 10$ & - \\
\hline Caproate & + & Activity of: & \\
\hline L-Glutamic acid & + & Cystine arylamidase & + \\
\hline Cellobiose & + & Alkaline phosphatase & + \\
\hline L-Arabinose & + & Esterase (C4) & + \\
\hline Glycerol & + & Esterase lipase (C8) & + \\
\hline L-Alanine & + & Lipase (C14) & + \\
\hline Proline & + & Leucine arylamidase & + \\
\hline Serine & + & Valine arylamidase & + \\
\hline Autotrophic growth with $\mathrm{H}_{2}, \mathrm{~S}^{0}$ or $\mathrm{S}_{2} \mathrm{O}_{3}^{2-}$ & - & Acid phosphatase & + \\
\hline Reduction of nitrate & - & Naphthol-AS-BI-phosphohydrolase & + \\
\hline Anaerobic growth with nitrate & - & $\beta$-Glucosidase & + \\
\hline $\mathrm{N}_{2}$ used as nitrogen source & - & Amylase & - \\
\hline $\mathrm{Mn}^{2+}$ oxidation & - & Tweenase (Tween 80) & + \\
\hline Requirement for growth factors (vitamins or amino acids) & - & Hydrogenase activity & + \\
\hline Degradation of polycaprolactone oxydiethylene ester & + & & \\
\hline
\end{tabular}

Table 2. Fatty acid composition of strain $\mathrm{N} 2-680^{\top}$

Values are percentages of total fatty acids. Components representing $<1 \%$ of total fatty acids are summarized under 'Other' and include iso- $\mathrm{C}_{11: 0} 3-\mathrm{OH}, \mathrm{C}_{14: 0}$ and $\mathrm{C}_{17: 0}$.

\begin{tabular}{|lrr|}
\hline Fatty acid & $\mathbf{5 0}^{\circ} \mathbf{C}$ & $\mathbf{3 0}^{\circ} \mathbf{C}$ \\
\hline $\mathrm{C}_{10: 0}$ 3-OH & $2 \cdot 8$ & $3 \cdot 5$ \\
$\mathrm{C}_{10: 0}$ & $1 \cdot 4$ & $1 \cdot 2$ \\
$\mathrm{C}_{12: 0}$ 3-OH & $1 \cdot 9$ & $1 \cdot 9$ \\
$\mathrm{C}_{12: 0}$ & $1 \cdot 6$ & $1 \cdot 6$ \\
iso- $\mathrm{C}_{16: 0}$ & $2 \cdot 2$ & $0 \cdot 5$ \\
$\mathrm{C}_{16: 0}$ & $44 \cdot 2$ & $23 \cdot 7$ \\
$\mathrm{C}_{16: 1}$ & $3 \cdot 7$ & $29 \cdot 0$ \\
cyclo-C & $27 \cdot 6$ & $6 \cdot 5$ \\
$\mathrm{C}_{18: 0}$ & $2 \cdot 7$ & $2 \cdot 3$ \\
$\mathrm{C}_{18: 1}$ & $5 \cdot 7$ & $27 \cdot 7$ \\
cyclo- $\mathrm{C}_{19: 0}(\omega 8 \mathrm{c})$ & $3 \cdot 1$ & $0 \cdot 1$ \\
Other & $3 \cdot 1$ & $2 \cdot 0$ \\
Total & $100 \cdot 0$ & $100 \cdot 0$ \\
\hline
\end{tabular}

of chain unsaturation (Manaia \& Moore 2002; Busse et al., 2002).

The $\mathrm{G}+\mathrm{C}$ content of genomic DNA of strain $\mathrm{N} 2-680^{\mathrm{T}}$ was $70 \cdot 1 \mathrm{~mol} \%$. Nearly the complete $16 \mathrm{~S}$ rDNA sequence of strain $\mathrm{N} 2-680^{\mathrm{T}}$ was determined (1435 nucleotide positions) and compared with reference sequences in databases. Phylogenetic analysis of the $16 \mathrm{~S}$ rDNA sequence of strain $\mathrm{N} 2-680^{\mathrm{T}}$ showed its affiliation to the $\beta$-subclass of the Proteobacteria, being most closely related to the genera Ideonella, Leptothrix, Rubrivivax and Aquabacterium and the species Alcaligenes latus, as shown in Fig. 1. The highest sequence similarities were to Leptothrix mobilis DSM $10617^{\mathrm{T}}$ and Ideonella dechloratans CCUG $30898^{\mathrm{T}}(95 \cdot 7 \%$ sequence similarity).

Considerable physiological heterogeneity characterizes the sub-branch Rubrivivax-Roseateles-Leptothrix-IdeonellaAquabacterium of the $\beta$-Proteobacteria. Among the few common characteristics attributed to members of this phylogenetic lineage are the accumulation of $\mathrm{PHB}$ granules, 


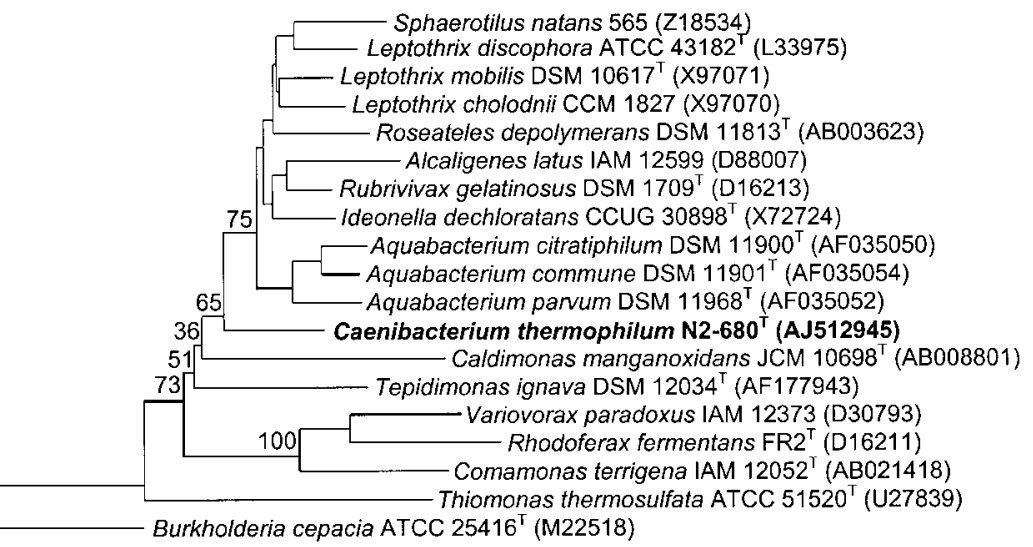

$0 \cdot 05$
Fig. 1. Phylogenetic relationships of the 16S rDNA sequence of strain $N 2-680^{\top}$ with related genera within the $\beta$-subclass of the Proteobacteria. Evolutionary-distance matrices were calculated using the correction of Jukes \& Cantor (1969). The dendrogram was constructed using the FITCH program included in PHYLIP (Felsenstein, 1989). The 16S rDNA sequence of Burkholderia cepacia ATCC $25416^{\top}$ was used as the outgroup. Bootstrap values of relevant branches obtained after 1000 replicates are indicated at the nodes. the presence of ubiquinone 8 and a DNA base composition ranging from 66 to $72 \mathrm{~mol} \% \mathrm{G}+\mathrm{C}$. The fatty acid composition is not published for all species with validly published names within this phylogenetic lineage; however, based on the data available (Busse \& Auling, 1992; Spring et al., 1996; Takeda et al., 2002), the predominance of the fatty acids $C_{16: 0}, C_{16: 1}$ and $C_{18: 1}$ seems to represent another feature of this group. As presented in Tables 1-3, strain $\mathrm{N} 2-680^{\mathrm{T}}$ shares all these characteristics with its closest phylogenetic neighbours.

One important characteristic that distinguishes strain $\mathrm{N} 2-680^{\mathrm{T}}$ from its closest phylogenetic neighbours, i.e. members of the genera Rubrivivax, Leptothrix, Ideonella

Table 3. Characteristics of strain $\mathrm{N} 2-680^{\top}$ and related species

Taxa: 1, strain $\mathrm{N} 2-680^{\mathrm{T}}$; 2, Alcaligenes latus; 3, Rubrivivax gelatinosus; 4, Leptothrix mobilis; 5, Ideonella dechloratans; 6, Aquabacterium commune; 7, Caldimonas manganoxidans; 8, Tepidimonas ignava. Data were obtained from Busse \& Auling (1992), Kalmbach et al. (1999), Malmqvist et al. (1994), Moreira et al. (2000), Palleroni \& Palleroni (1978), Spring et al. (1996), Takeda et al. (2002) and Willems et al. (1991). NA, No data available; d, variable result within the species.

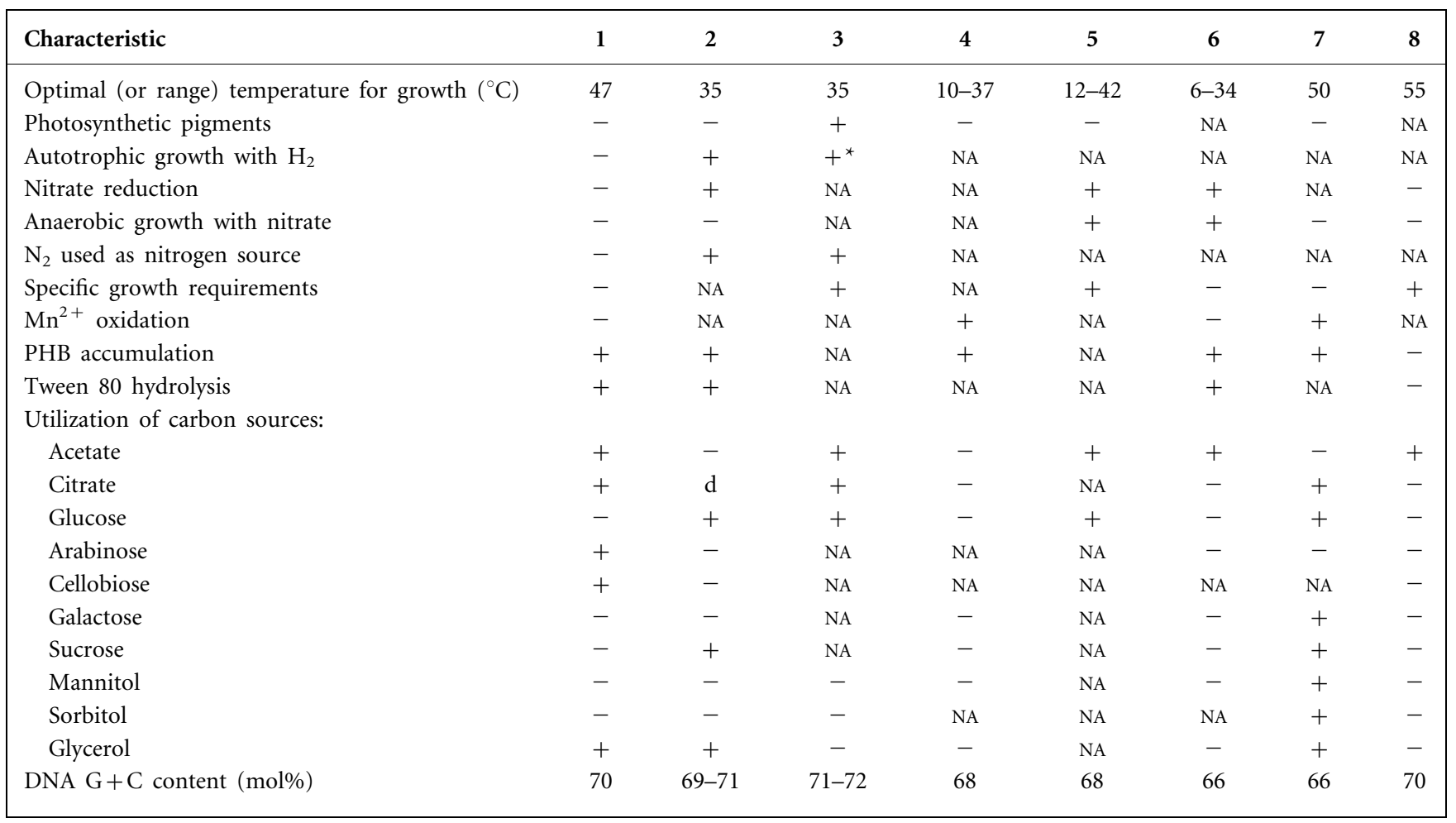

${ }^{\star}$ Photoautotrophic growth. 
and Aquabacterium and the species Alcaligenes latus, is the temperature range of growth. Strain $\mathrm{N} 2-680^{\mathrm{T}}$ differs from species of the genus Leptothrix in the absence of a cell sheath and the inability to produce manganese oxides, as is typical for these organisms (Siering \& Ghiorse, 1996). Characteristics that differentiate strain $\mathrm{N} 2-680^{\mathrm{T}}$ from Leptothrix mobilis include the capacity to use acetate, citrate and glycerol as single carbon sources. The presence of photosynthetic pigments, described for members of Rubrivivax gelatinosus (Willems et al., 1991), constitutes another distinction between isolate $\mathrm{N} 2-680^{\mathrm{T}}$ and this species. Members of Alcaligenes latus can grow autotrophically in the presence of hydrogen gas, are able to reduce nitrate and can fix nitrogen (Palleroni \& Palleroni, 1978; Busse \& Auling, 1992). All these characteristics were absent for isolate N2-680 ${ }^{\mathrm{T}}$. The presence of catalase, the use of carbohydrates as sole carbon sources and the inability to reduce nitrate and to grow anaerobically with nitrate allow distinction between isolate $\mathrm{N} 2-680^{\mathrm{T}}$ and Aquabacterium species (Kalmbach et al., 1999). Ideonella dechloratans differs from isolate $\mathrm{N} 2-680^{\mathrm{T}}$ in the ability to use glucose as a single carbon source and in the capacity to reduce nitrate (Malmqvist et al., 1994).

More distantly related phylogenetic neighbours of strain $\mathrm{N} 2-680^{\mathrm{T}}$ are the thermophilic species Caldimonas manganoxidans and Tepidimonas ignava, which share $16 \mathrm{~S}$ rDNA sequence identity of 93.6 and $94 \cdot 7 \%$, respectively, with the novel isolate. Despite the fact that the three organisms are thermophilic, the comparatively low values of $16 \mathrm{~S}$ rDNA sequence identity and the differences observed for other phenotypic traits are consistent with the definition of distinct genera. Caldimonas manganoxidans can be distinguished from strain $\mathrm{N} 2-680^{\mathrm{T}}$ by its ability to oxidize manganese and to use malate, mannitol, sorbitol, D-glucose, D-galactose, maltose and sucrose as single carbon sources (Takeda et al., 2002). Tepidimonas ignava differs from strain $\mathrm{N} 2-680^{\mathrm{T}}$ in the absence of PHB granules, the inability to grow in the presence of $3 \% \mathrm{NaCl}$ and to hydrolyse Tween 80 , the requirement for specific growth factors, the inability to use arabinose, cellobiose and glycerol and the ability to use malate and asparagine as single carbon sources. Moreover, the optimum temperature for growth of Tepidimonas ignava is $55^{\circ} \mathrm{C}$, slightly higher than that observed for strain N2$680^{\mathrm{T}}$ (Moreira et al., 2000). The phylogenetic position of strain $\mathrm{N} 2-680^{\mathrm{T}}$, along with its phenotypic characteristics, support the description of a new genus. Characteristics that differentiate between strain $\mathrm{N} 2-680^{\mathrm{T}}$, its phylogenetic closest relatives and the thermophilic species more phylogenetically closely related to this isolate are summarized in Table 3 .

Based on FASTA analysis, isolate $\mathrm{N} 2-680^{\mathrm{T}}$ showed $99 \cdot 9 \% 16 \mathrm{~S}$ rDNA identity to a thermophilic organism, strain DhA-71 (EMBL accession no. AF125876), described as capable of degrading dehydroabietic acid (Yu \& Mohn, 1999), indicating that the two isolates might belong to the same species. Strain DhA-71 was isolated from municipal compost in Canada, whereas strain $\mathrm{N} 2-680^{\mathrm{T}}$ was recovered from a thermophilic sludge digester in Portugal, suggesting that this species may have a widespread distribution in such habitats.

The phenotypic and chemotaxonomic characterization of strain $\mathrm{N} 2-680^{\mathrm{T}}$ and $16 \mathrm{~S}$ rDNA-based phylogenetic analysis revealed that this bacterium is not affiliated to any validly named genus. The definition of the new genus Caenibacterium gen. nov., containing the species Caenibacterium thermophilum sp. nov., is proposed, with isolate $\mathrm{N} 2-680^{\mathrm{T}}$ as the type strain.

\section{Description of Caenibacterium gen. nov.}

Caenibacterium (Cae' ni.bac.te.ri.um. L. n. caenum mud, sludge; N.L. n. bacterium from Gr. n. bakterion rod; N.L. neut. n. Caenibacterium a rod-shaped bacterium isolated from sludge).

Forms rod-shaped cells that stain Gram-negative, with a polar flagellum. Endospores are not formed. PHB granules are accumulated. Oxidase and catalase are positive. Slightly thermophilic. Major phospholipids are phosphatidylethanolamine and phosphatidylglycerol; ubiquinone 8 is the major respiratory quinone. Major fatty acids include $\mathrm{C}_{16: 0}, \mathrm{C}_{16: 1}$ and $\mathrm{C}_{18: 1}$ or its secondary products such as cyclo- $\mathrm{C}_{17: 0}$. The hydroxylated fatty acids $3-\mathrm{OH}-\mathrm{C}_{10: 0}$ and $3-\mathrm{OH}-\mathrm{C}_{12: 0}$ are present. Nitrate is not reduced, photosynthetic pigments are not present and $\mathrm{Mn}^{2+}$ is not oxidized. No autotrophic growth occurs. Chemo-organotrophic. Organic acids, amino acids and hydrocarbons are used as single carbon sources. The type species is Caenibacterium thermophilum.

\section{Description of Caenibacterium thermophilum sp. nov.}

Caenibacterium thermophilum (ther.mo'phi.lum. Gr. n. therme warm; Gr. adj. philos friendly to; N.L. neut. adj. thermophilum loving warmth, thermophilic).

Forms rod-shaped cells, $1.3 \mu \mathrm{m}$ long and $0.5 \mu \mathrm{m}$ wide. A single polar flagellum is observed at the early stages of growth. Colonies grown on LB agar are non-pigmented, slightly brilliant and 1-2 $\mathrm{mm}$ in diameter after $36-48 \mathrm{~h}$ growth. Growth occurs above $25^{\circ} \mathrm{C}$ and below $57^{\circ} \mathrm{C}$; the optimal growth temperature is approximately $47^{\circ} \mathrm{C}$. Growth occurs between $\mathrm{pH} 6$ and 9. Hydrogenase- and tweenasepositive. Acetate, citrate, gluconate, caproate, glutamic acid, cellobiose, arabinose, glycerol, alanine, proline and serine are used as single carbon sources. Capable of degradation of polycaprolactone oxydiethylene ester. The major fatty acids at $50{ }^{\circ} \mathrm{C}$ are $\mathrm{C}_{16: 0}$ and cyclo- $\mathrm{C}_{17: 0}$. The DNA G+C content of the type strain is $70 \cdot 1 \mathrm{~mol} \%$.

The type strain, strain $\mathrm{N} 2-680^{\mathrm{T}}\left(=\mathrm{DSM} 15264^{\mathrm{T}}=\mathrm{LMG}\right.$ $21760^{\mathrm{T}}$ ), was isolated from a thermophilic aerobic digester of wastewater-treatment sludge.

\section{ACKNOWLEDGEMENTS}

C. M. M. thanks Nuno Cerca and Nuno Marcos from Escola Superior de Biotecnologia for their collaboration in the preparation of the 
enrichment cultures and Fernanda Nobre from Departamento de Zoologia da Universidade de Coimbra for FAME analyses. The authors thank Solvay, UK, for the caprolactones and ETAR de Parada, Maia, Portugal, for the sampling.

\section{REFERENCES}

Aragno, M. \& Schlegel, H. G. (1992). The mesophilic hydrogen oxidizing (Knallgas) bacteria. In The Prokaryotes, 2nd edn, pp. 3917-3933. Edited by A. Balows, H. G. Trüper, M. Dworkin, W. Harder \& K.-H. Schleifer. New York: Springer.

Busse, H. J. \& Auling, G. (1992). The genera Alcaligenes and 'Achromobacter'. In The Prokaryotes, 2nd edn, pp. 2544-2555. Edited by A. Balows, H. G. Trüper, M. Dworkin, W. Harder \& K.-H. Schleifer. New York: Springer.

Busse, H.-J., Kämpfer, P., Moore, E. R. B. \& 7 other authors (2002). Thermomonas haemolytica gen. nov., sp. nov., a $\gamma$-proteobacterium from kaolin slurry. Int J Syst Evol Microbiol 52, 473-483.

Carlton, B. C. \& Brown, B. J. (1981). Gene mutation. In Manual of Methods for General Bacteriology, pp. 409-443. Edited by P. Gerhardt, R. G. E. Murray, R. N. Costilow, E. W. Nester, W. A. Wood, N. R. Krieg \& G. H. Phillips. Washington, DC: American Society for Microbiology.

Cashion, P., Holder-Franklin, M. A., McCully, J. \& Franklin, M. (1977). A rapid method for the base ratio determination of bacterial DNA. Anal Biochem 81, 461-466.

Doetsch, R. N. (1981). Determinative methods of light microscopy, In Manual of Methods for General Bacteriology, pp. 21-33. Edited by P. Gerhardt, R. G. E. Murray, R. N. Costilow, E. W. Nester, W. A. Wood, N. R. Krieg \& G. H. Phillips. Washington, DC: American Society for Microbiology.

Felsenstein, J. (1989). PHYLIP - phylogeny inference package. Cladistics 5, 164-166.

Heimbrook, M. E., Wang, W. L. L. \& Campbell, G. (1989). Staining bacterial flagella easily. J Clin Microbiol 27, 2612-2615.

Jukes, T. H. \& Cantor, C. R. (1969). Evolution of protein molecules. In Mammalian Protein Metabolism, pp. 21-132. Edited by $\mathrm{H}$. N. Munro. New York: Academic Press.

Kalmbach, S., Manz, W., Wecke, J. \& Szewzyk, U. (1999). Aquabacterium gen. nov., with description of Aquabacterium citratiphilum sp. nov., Aquabacterium parvum sp. nov. and Aquabacterium commune sp. nov., three in situ dominant bacterial species from the Berlin drinking water system. Int J Syst Bacteriol 49, 769-777.

Kuykendall, L. D., Roy, M. A., O'Neill, J. J. \& Devine, T. E. (1988). Fatty acids, antibiotic resistance, and deoxyribonucleic acid homology groups of Bradyrhizobium japonicum. Int J Syst Bacteriol 38, 358-361.

Lane, D. J. (1991). 16S/23S rRNA sequencing. In Nucleic Acid Techniques in Bacterial Systematics, pp. 115-175. Edited by E. Stackebrandt \& M. Goodfellow. Chichester: Wiley.

Malmqvist, A., Welander, T., Moore, E., Ternström, A., Molin, G. \& Sternström, I. (1994). Ideonella dechloratans, gen. nov., sp. nov., a new bacterium capable of growing anaerobically with chlorate as an electron acceptor. Syst Appl Microbiol 17, 58-64.

Manaia, C. M. \& Moore, E. R. B. (2002). Pseudomonas thermotolerans sp. nov., a thermotolerant species of the genus Pseudomonas sensu stricto. Int J Syst Evol Microbiol 52, 2203-2209.

Mesbah, M., Premachandran, U. \& Whitman, W. B. (1989). Precise measurement of the $\mathrm{G}+\mathrm{C}$ content of deoxyribonucleic acid by highperformance liquid chromatography. Int J Syst Bacteriol 39, 159-167.
Moreira, C., Rainey, F. A., Nobre, M. F., da Silva, M. T. \& da Costa, M. S. (2000). Tepidimonas ignava gen. nov., sp. nov., a new chemolithohererotrophic and slightly thermophilic member of the $\beta$-Proteobacteria. Int J Syst Evol Microbiol 50, 735-742.

Mulder, E. G. (1989). Genus Leptothrix Kützing 1843, $198^{\mathrm{AL}}$. In Bergey's Manual of Systematic Bacteriology, vol. 3, pp. 1998-2003. Edited by J. T. Staley, M. P. Bryant, N. Pfennig \& J. G. Holt. Baltimore: Williams \&Wilkins.

Mulder, E. G. \& Deinema, M. H. (1992). The sheathed bacteria. In The Prokaryotes, 2nd edn, pp. 2612-2624. Edited by A. Balows, H. G. Trüper, M. Dworkin, W. Harder \& K.-H. Schleifer. New York: Springer.

Nealson, K. H. (1992). The manganese-oxidizing bacteria. In The Prokaryotes, 2nd edn, pp. 2310-2320. Edited by A. Balows, H. G. Trüper, M. Dworkin, W. Harder \& K.-H. Schleifer. New York: Springer.

Nogales, B., Moore, E. R. B., Llobet-Brossa, E., Rossello-Mora, R., Amann, R. \& Timmis, K. N. (2001). Combined use of 16 S ribosomal DNA and $16 \mathrm{~S}$ rRNA to study the bacterial community of polychlorinated biphenyl-polluted soil. Appl Environ Microbiol 67, 1874-1884.

Palleroni, N. J. \& Palleroni, A. V. (1978). Alcaligenes latus, a new species of hydrogen-utilizing bacteria. Int J Syst Bacteriol 28, 416-424.

Pearson, W. R. \& Lipman, D. J. (1988). Improved tools for biological sequence comparison. Proc Natl Acad Sci U S A 85, 2444-2448.

Pfennig, N. (1978). Rhodocyclus purpureus gen. nov. and sp. nov., a ring-shaped, vitamin $\mathrm{B}_{12}$-requiring member of the family Rhodospirillaceae. Int J Syst Bacteriol 28, 283-288.

Prado, A., da Costa, M. S. \& Madeira, V. M. C. (1988). Effect of growth temperature on the lipid composition of two strains of Thermus sp. J Gen Microbiol 134, 1653-1660.

Siefert, E., Irgens, R. L. \& Pfennig, N. (1978). Phototrophic purple and green bacteria in a sewage treatment plant. Appl Environ Microbiol 35, 38-44.

Siering, P. L. \& Ghiorse, W. C. (1996). Phylogeny of the SphaerotilusLeptothrix group inferred from morphological comparisons, genomic fingerprinting, and $16 \mathrm{~S}$ ribosomal DNA sequence analyses. Int J Syst Bacteriol 46, 173-182.

Smibert, R. M. \& Krieg, N. R. (1981). General characterization. In Manual of Methods for General Bacteriology, pp. 409-443. Edited by P. Gerhardt, R. G. E. Murray, R. N. Costilow, E. W. Nester, W. A. Wood, N. R. Krieg \& G. H. Phillips. Washington, DC: American Society for Microbiology.

Spring, S., Kämpfer, P., Ludwig, W. \& Schleifer, K. H. (1996). Polyphasic characterization of the genus Leptothrix: new descriptions of Leptothrix mobilis sp. nov. and Leptothrix discophora sp. nov. nom. rev. and emended description of Leptothrix cholodnii emend. Syst Appl Microbiol 19, 634-643.

Stöhr, R., Waberski, A., Liesack, W., Völker, H., Wehmeyer, U. \& Thomm, M. (2001). Hydrogenophilus hirschii sp. nov., a novel thermophilic hydrogen-oxidizing $\beta$-proteobacterium isolated from Yellowstone National Park. Int J Syst Evol Microbiol 51, 481-488.

Suyama, T., Hosoya, H. \& Tokiwa, Y. (1998). Bacterial isolates degrading aliphatic polycarbonates. FEMS Microbiol Lett 161, 255-261.

Suyama, T., Shigematsu, T., Takaichi, S., Nodasaka, Y., Fujikawa, S., Hosoya, H., Tokiwa, Y., Kanagawa, T. \& Hanada, S. (1999). Roseateles depolymerans gen. nov., sp. nov., a new bacteriochlorophyll $a$-containing obligate aerobe belonging to the $\beta$-subclass of the Proteobacteria. Int J Syst Bacteriol 49, 449-457.

Suzuki, K., Goodfellow, M. \& O’Donnell, A. G. (1993). Cell envelopes and classification. In Handbook of New Bacterial Systematics, 
pp. 195-250. Edited by M. Goodfellow \& A. G. O’Donnell. London: Academic Press.

Takeda, M., Koizumi, J., Yabe, K. \& Adachi, K. (1998). Thermostable poly(3-hydroxybutyrate) depolymerase of a thermophilic strain of Leptothrix sp. isolated from a hot spring. J Ferment Bioeng 85, 375-380.

Takeda, M., Kamagata, Y., Ghiorse, W. C., Hanada, S. \& Koizumi, J. (2002). Caldimonas manganoxidans gen. nov., sp nov., a poly(3hydroxybutyrate)-degrading, manganese-oxidizing thermophile. Int J Syst Evol Microbiol 52, 895-900.

Tindall, B. J. (1989). Fully saturated menaquinones in the archaebacteriun Pyrobaculum islandicum. FEMS Microbiol Lett 60, 251-254.
Wilkinson, S. G. (1988). Gram-negative bacteria. In Microbial Lipids, vol. 1, pp. 299-488. Edited by C. Ratledge \& S. G. Wilkinson. London: Academic Press.

Willems, A., Gillis, M. \& De Ley, J. (1991). Transfer of Rhodocyclus gelatinosus to Rubrivivax gelatinosus gen. nov., comb. nov., and phylogenetic relationships with Leptothrix, Sphaerotilus natans, Pseudomonas saccharophila, and Alcaligenes latus. Int $J$ Syst Bacteriol 41, 65-73.

Yu, Z. \& Mohn, W. W. (1999). Isolation and characterization of thermophilic bacteria capable of degrading dehydroabietic acid. Can J Microbiol 45, 513-519. 